Article

\title{
Energy and Sustainable Strategies in the Renovation of Existing Buildings: An Italian Case Study
}

\author{
Pierluigi de Berardinis, Marianna Rotilio * and Luisa Capannolo \\ Department of Civil, Architecture, Environmental Engineering, University of Studies of L'Aquila, \\ 61700 L'Aquila, Italy; pierluigi.deberardinis@univaq.it (P.d.B.); luisa.capannolo@yahoo.it (L.C.) \\ * Correspondence: mariannarotilio@hotmail.com; Tel.: +39-349-610-2863
}

Received: 6 July 2017; Accepted: 16 August 2017; Published: 19 August 2017

\begin{abstract}
The re-use of historical buildings, in some cases those that have been abandoned for years, is currently generating a lot of interest, and brings into discussion topics such as land recycling and the use of new resources. Our project on the rehabilitation of the former San Salvatore hospital in L'Aquila is an example of this re-use, and illustrates how best-practice strategies can be implemented in the rehabilitation of an existing building. There were two themes of evaluation: firstly, the adaptive re-use of a historical building of great impact in a strategic position within the urban core; secondly, the implementation of sustainable strategies when upgrading both the building envelope and building systems.
\end{abstract}

Keywords: sustainable energy strategies; innovative technologies; existing building

\section{Introduction}

The Italian peninsula, from north to south, is full of abandoned structures, not only in the suburbs, but also within historical centers. Some have been transformed, but these transformations can rarely be taken as a model to imitate, whilst plans for others have been lost in bureaucratic delays and failures of institutions to act in time. Understanding how the enhancement and renovation of existing buildings can be accomplished without the need for new building and further loss of land to construction requires reflection on how action can be taken across such a vast context, encompassing varying and considerable interests.

According to Legambiente [1], only 45\% of public buildings in Italy were built before 1945, and more than $55 \%$ of the country's built heritage was built before the eighties. In Europe, approximately $35 \%$ of buildings are currently more than 50 years old [2]. These buildings are seldom equipped with adequate insulation systems or facilities, and for this reason, they are referred to as "eco-monsters"; in other words, they are highly energy-consuming buildings. Privately owned, disused building stock (some sources indicate approximately 5 million units in Italy) is in the same critical condition, with the worst affected being historical villages, many of which are in an irreversible state of neglect. The motivation behind the research illustrated below is the knowledge that action is required for our abandoned or neglected built heritage rather than for vacant areas [3].

The implementation of strategies aimed at promoting energy efficiency and limiting energy consumption is clearly a fundamental aspect of renovation today. In central Italy, the effect of recent earthquakes and subsequent interventions on buildings has generated an unexpected meeting of interests by combining renovation and energy efficiency improvement of buildings, through the use of high-performance and high-quality energy systems [4]. In this context, the rehabilitation project of an old, decommissioned hospital in L'Aquila was a unique opportunity to improve the community's built heritage. In fact, "Community residents have a strong stake in a local heritage site and may be an important force in its conservation, management and development. Positive relationships between 
the heritage site and community residents can promote its protection" [5]. Mapping out a model to follow for reference for future projects was a logical consequence of this work, as the building had a highly symbolic value for the city of Aquila. Semprini et al. [6] analyzed a public building, making some minor modifications to improve the energy efficiency and they obtained some very promising results [2].

Our research aims were therefore the following:

1 A complete rehabilitation of the building in relation to its functional, spatial, aesthetic, energetic and structural aspects, so as to give it a new role also in terms of architecture, considering its strategic position within the urban fabric.

2 Sustainability in terms of meeting energy efficiency requirements, reducing environmental impact and improving comfort and quality of the interior spaces of the public buildings in line with European policies. "In Europe, the legislation concerning this area is based on the certification of energy efficiency, developed in the early 1990s as a primary strategy to reduce energy use and carbon emissions as well as the energy policy adopted in 2007, called Horizon 20-20-20" [2,7,8].

Our objectives in this regard were the following:

- Compliance with current environmental and sanitary standards;

- Modernization of the technological system;

- Rehabilitation of the aesthetic and functional system;

- Structural strengthening of the building;

- Compliance with contemporary lighting standards;

- Introduction of renewable energy;

- Energy efficiency improvement of the building envelope.

We have endeavored to cover all of the above in this paper, although our main focus was on strategies that need to be implemented in order to improve the energy performance of the building envelope [9]. In fact, the building envelope is an energy-passive element, but the key element for ensuring the efficient performance of the whole building system [10].

\section{Materials and Methods}

A multi-disciplinary, holistic approach that takes into account cultural, historical, architectural, functional, aesthetic, structural, energy saving, economic and environmental aspects is necessary for the rehabilitation of a historical building. The study of these aspects is also important for identifying the most appropriate technological and design solutions [8,11]. Hence, the first step is the "study" of the building [12,13] in order to understand the aspects that identify and characterize it. However, in more complex contexts, it may not be possible to identify pre-established solutions, and a more "identitarian" approach is necessary that is more flexible and specific for the single case under consideration.

The methodology adopted in the first stage includes investigations and assessments aimed at gaining accurate knowledge of the building in order to identify the best possible design solutions that are compatible, reversible and most importantly in line with the values and identity of the building itself [14].

The methodological procedure has been developed through a careful assessment of the following aspects [15]:

- Implementation of surveys to analyze;

- Identification of the existing critical issues;

- Definition of the values to preserve and the level of transformability of the building;

- Elaboration of the design strategies;

- Compatibility check of the solutions proposed;

- Assessment of the improvement levels reached [8]. 
The analyses are both direct and indirect, and their implementation involves different steps and passages from macro to micro. The survey phase involved:

- Functional analyses of the territorial and urban context (urban and territorial context, metric surveys, historical background, origins and development of the building under study ...);

- Analysis of the construction structure;

- Thermal analyses;

- Bioclimatic analyses (solar shading, incident solar radiation and ventilation).

This survey phase was undertaken in light of European state-of-the-art work regarding similar projects of rehabilitation of heritage buildings [9,16-18]. In fact, "many publications studied the new measures to incorporate them into university buildings and how these could affect in the energy costs of local authorities. Trying to achieve this goal of energy sustainability, governments have included new policies to improve both energy saving and renewable energy; for example, the inclusion of light-emitting diodes (LEDs) in indoor lighting instead of the old incandescent bulbs" $[2,19,20]$.

These analyses were carried out to identify the values to be preserved (historic, architectural, landscape) as well as changeable elements (accretions, incoherent or highly-degraded elements). The results of these analyses highlight critical issues-environmental, structural, and/or relating to plumbing, electrical and/or gas systems-and were used to establish the design strategies to be implemented. The last step involved verifying the improvement levels generated by the design solutions selected.

The intervention on a complex and historical building, like our case study, raises issues that go beyond the simple process of rehabilitation and energy performance adjustment, since it is also necessary to include a careful process of re-arrangement and re-purposing of the space, defining new patterns of use. Furthermore, since the intervention involves a historical context to be rehabilitated, the designer must take into account many other aspects, such as the presence of variables, constraints, specific surrounding context, etc. In fact, the case study in this paper was once a hospital, but will never be reclassified for the same use, as current therapeutic needs and the energy efficiency levels required today are not compatible with the structure of old building types. The same applies to energy and environmental aspects, because they are now essential elements in the process of recovery and rehabilitation. It is evident that a multilayered approach is the only one possible. Indeed, problems have arisen as a result of insufficient exploration of types and methods of transformation in historical contexts and a lack of integral, interdisciplinary, planned approaches to the rehabilitation of space [12]. It should also be borne in mind the strict Italian norms in place, and the regulations set down by the authorities concerning buildings of cultural importance, which limit the approaches that can be taken.

The software programs used to process analyses and support the drafting of the project have had an important role in the development of our research. After analyzing differing types of software, we chose Ecotect and its add-on software Winair, Termus, Design Builder and PV Syst, based on a comparative analysis between software [21-24].

Ecotect software was used in solar analysis of the building complex in the context of its territory, as well as to calculate the incident solar radiation on all surfaces of the building. Winair software was used to study the natural ventilation of the building's surroundings. The steady-state energy simulation was implemented with Termus software, and the dynamic simulation with Design Builder software. The latter allowed us to quantify energy needs, the annual consumption, and the monthly values of comfort inside the building [21]. The PV Syst software was used for the design and installation of the photovoltaic system, and to evaluate its performance.

\section{Results}

\subsection{The Case Study: State-of-the-Art Analysis}

The former San Salvatore hospital, the city's main hospital up to the end of the twentieth century, is located in the northern part of the historical center of L'Aquila, near the city walls. Since the opening 
of a new hospital, the building has been left empty and devoid of any function, undergoing a gradual process of degradation, worsened by the serious damage caused by an earthquake that hit the city of L'Aquila in 2009 (Figure 1).
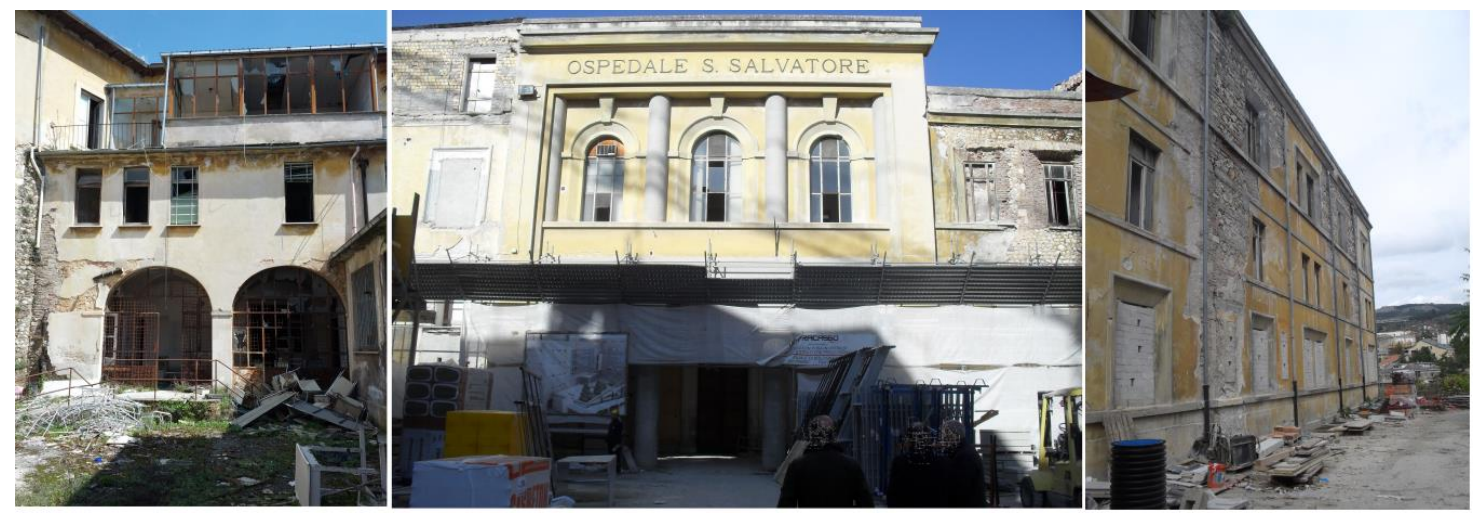

Figure 1. Current situation.

\subsubsection{Classification and Analysis of the Spatial Arrangement}

From an architectural point of view, the building complex is, at present, a heterogeneous and incoherent set of spaces in which the single elements cannot be recognized due to the many changes that have occurred over time, mainly to upgrade the sanitary and functional standards of the building. In fact, the hospital was set up in 1875 in a pre-existing building entailing inevitably structural changes right from that time.

In the early 1930's the hospital complex underwent expansion; indeed most of the extensions were built during this phase, giving the building a typical courtyard shape that is still recognizable today. Further extensions were added in the 1950s and 1960s due to the need for more space and since 1970, the building complex underwent continuous volumetric changes due to additions that altered the architectural and typological aspect, closing the courtyards built in the 1930s [25-29].

\subsubsection{Analysis of the Construction Structure}

The construction structure of the building complex, clearly visible due to the state of degradation of the plaster, is the result of the transformations undergone over this time. The analysis of vertical closures shows that the medieval core of the building has a structure of stone masonry, while in almost all of the remaining part of the building complex the stones are alternated every $60 \mathrm{~cm}$ to a double brick course, reinforced only in some portions of the structure with concrete pillars. As these construction elements do not have a homogeneous layered composition, the related energy and structural behaviors of the building are not linear with the consequent impossibility of assessing its performance (even the floors of the different portions of the building were built using different techniques). In fact, in the original medieval section, there are vaults or mixed slabs with iron and clay bricks (double $\mathrm{T}$ iron beams and vaults made of bricks or flooring blocks), whilst in the remaining part of the building there are floors made of hollow bricks and concrete slabs. The roofing structures are made of wood in all sections of the building, despite the fact they were built in different periods (Figure 2). 


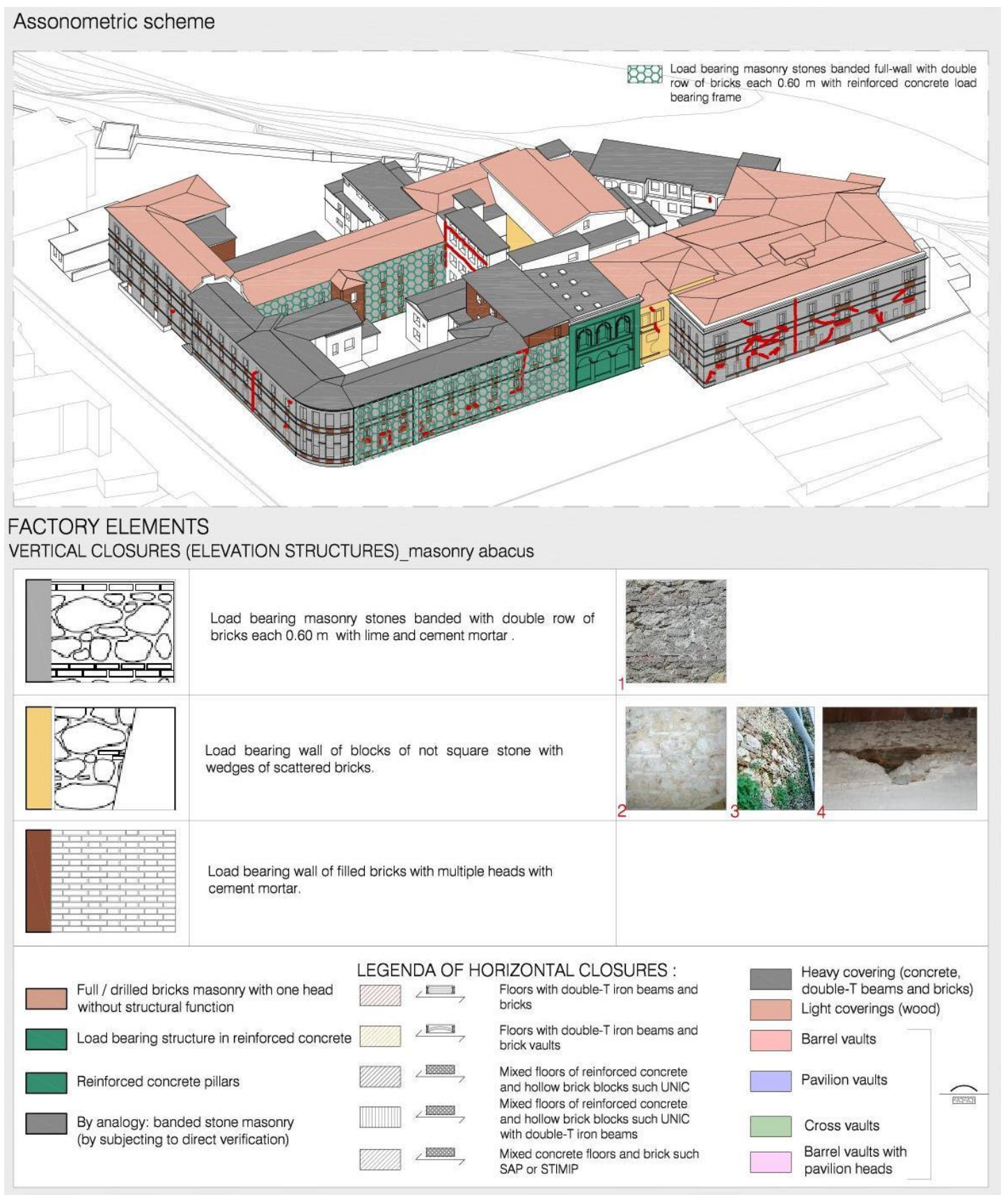

Figure 2. The constructive structure.

\subsubsection{Thermal Analyses}

Thermal analyses mainly refer to the elements making up the building envelope, for the reasons explained above. This activity was carried out through the integrated and synergistic use of new energy audit techniques, such as thermographic, thermo-hygrometric and heat flux analyses, which helped to significantly improve the quality and effectiveness of site investigation processes [17,30].

They were only used, however, for the portion of the building complex dating back to the 1950s. In fact, being the most damaged part of the building, it needs to undergo significant recovery work, both from a structural and energetic point of view (Figure 3). 

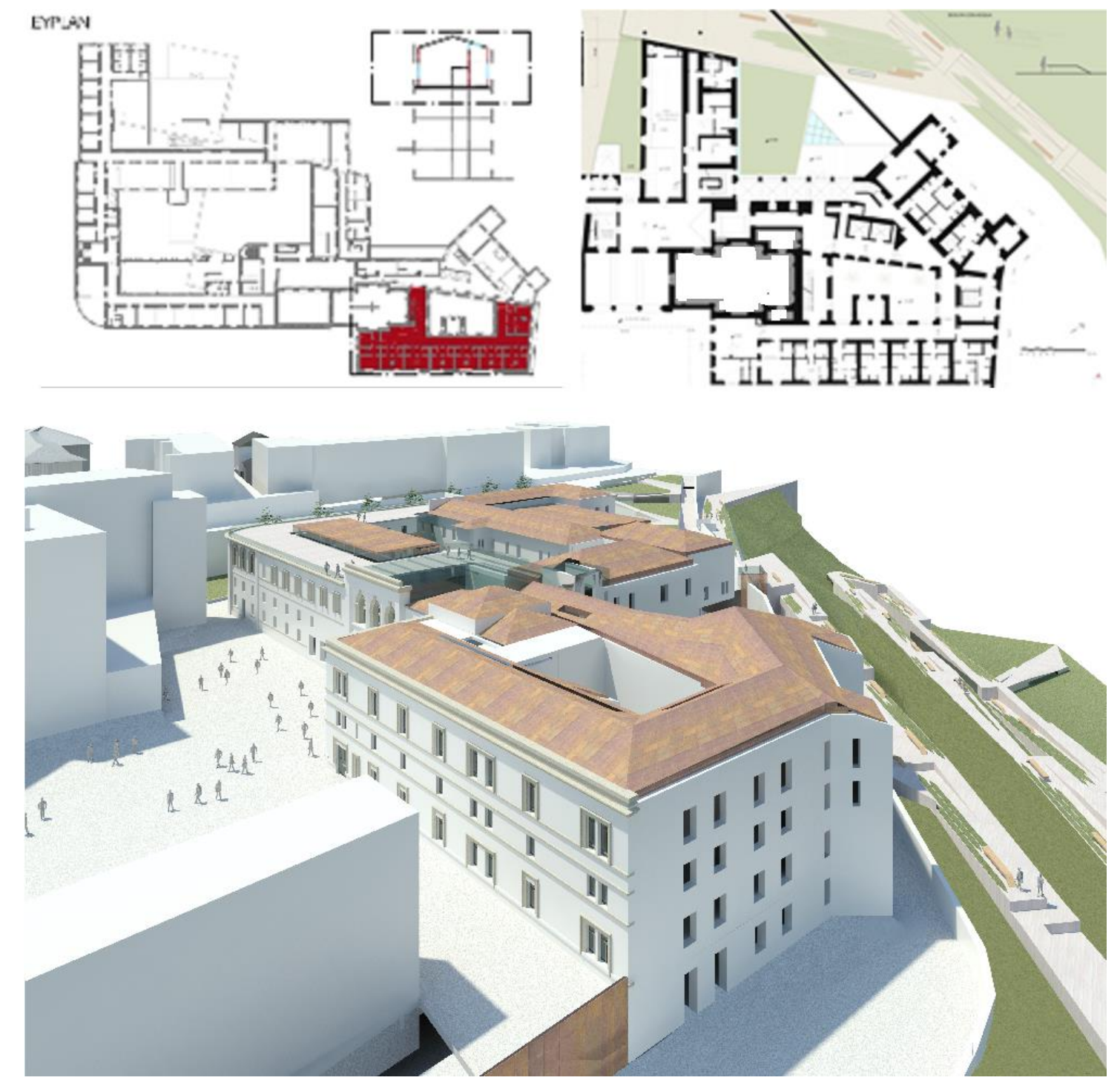

Figure 3. Location of part of the building studied in detail.

A series of problems have been revealed, from an energy perspective, with the type of masonry examined, especially in winter, mainly due to the lack of insulation. In contrast, in summer, thanks to the high thermal inertia of the stone walls, the masonry is able to deliver a good level of indoor comfort. The above-mentioned considerations derive from in-situ visual analyses, and are supported by the output data obtained from dynamic and steady-state simulations carried out with Termus software, and from dynamic state simulations using Design Builder software.

The thermal analysis of the vertical and horizontal closures in a steady state showed inadequate performance, with values of transmittance exceeding the maximum levels permitted by law (D.M. 26 June 2015-Ministerial Decree: "Adjustment of decree of the Minister for Economic Development, 26 June 2009-National guidelines for energy certification of buildings", in accordance with Article 6, paragraph 12 of Legislative Decree 19 August 2005, n. 192). We see, in fact, walls with U-values of $1.05 \mathrm{~W} / \mathrm{m}^{2} \mathrm{~K}$ and floors with U-values of $1.5 \mathrm{~W} / \mathrm{m}^{2} \mathrm{~K}$, compared to the limit values of 0.30 and $0.25 \mathrm{~W} / \mathrm{m}^{2} \mathrm{~K}$, respectively, required by law (Figure 4 ). 
CURRENT STATE

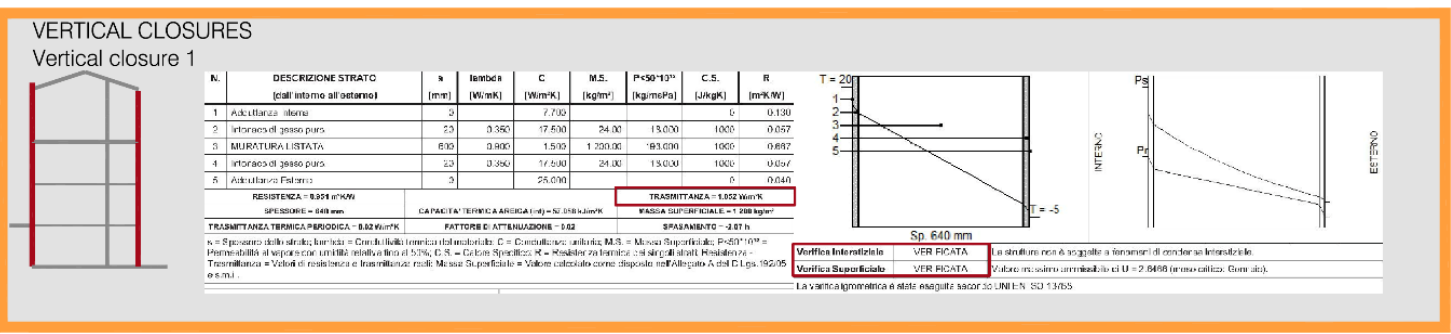

Figure 4. Thermal analysis of a wall in a steady state (current state).

The thermal analysis performed in a dynamic regime showed, consistent with the previous analysis, a high heating demand in winter of approximately $90.137 \mathrm{Wh} / \mathrm{m}^{2}$ and, conversely, a low cooling demand in summer of approximately $6.163 \mathrm{Wh} / \mathrm{m}^{2}$ (Figure 5). In the warmest month (August), in fact, the operating temperature was $24.72{ }^{\circ} \mathrm{C}$ and relative humidity was $52.47 \%$ (Figure 6).

The comfort curve indicates the quantitative levels of the main parameters that influence the thermal comfort in indoor environments, i.e., the operating temperature and relative humidity. As mentioned, the chart shows that the comfort conditions are good in summer, whilst in winter the operating temperature has low values.

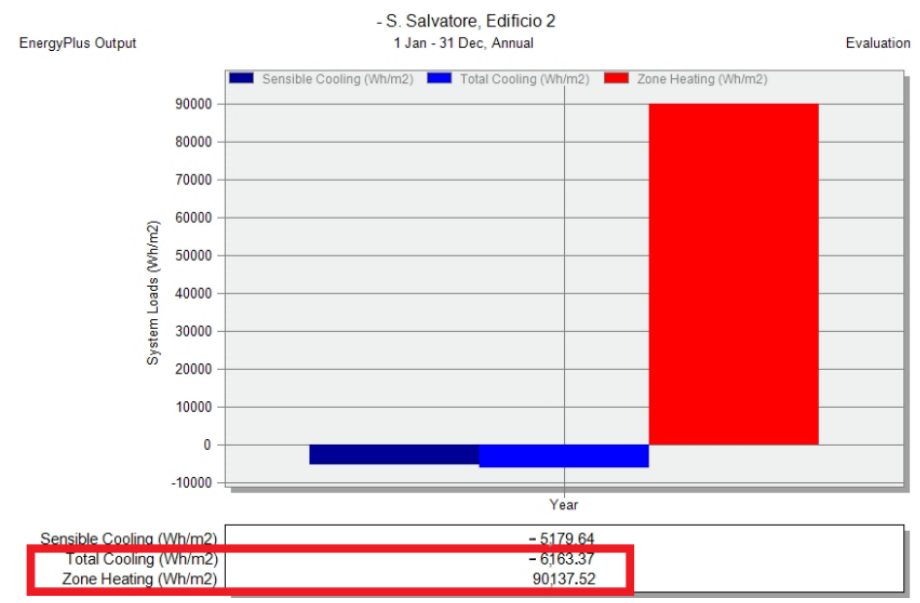

Figure 5. Total consumption of the building in dynamic regime, current situation.

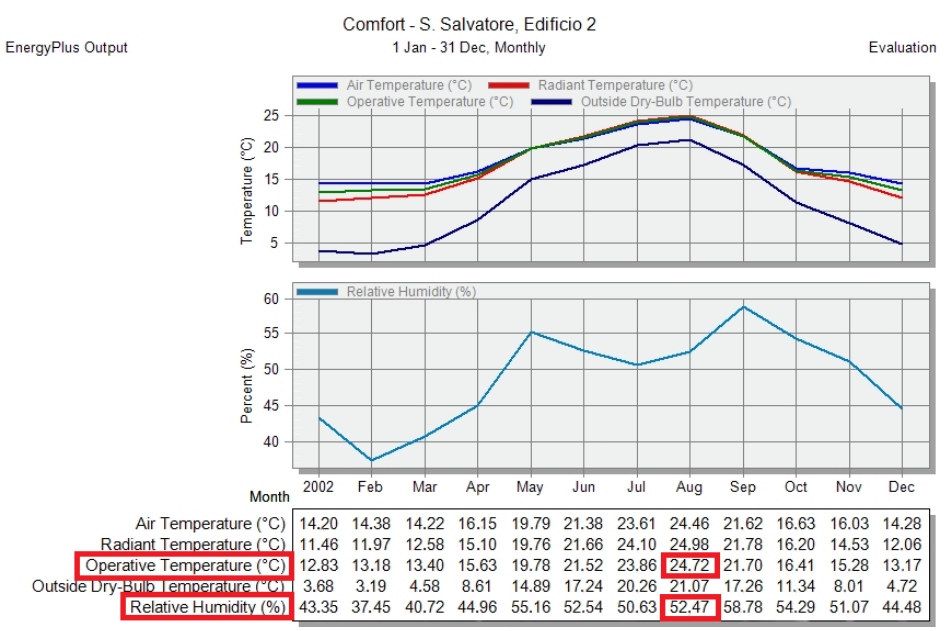

Figure 6. Monthly comfort curve (current state). 


\subsubsection{Bioclimatic Analyses}

Finally, additional semi-qualitative bioclimatic analyses were carried out on the entire building complex in its current state. Solar shading, incident solar radiation and ventilation analyses were carried out using the Ecotect and Winair software programs. These analyses highlighted other important issues with this historic building, in addition to the inefficient arrangement of the internal space, the state of decay and neglect and heavy structural damage already listed in chapter 2 of this paper.

However, these analyses also highlighted significant potential. For example, the qualitative analysis of solar shading, implemented at both global and specific levels in the various reference periods of the year and at different times of the day, showed that some indoor and outdoor spaces are in perpetual shade and some facades of the building complex receive a poor amount of daylight for much of the year.

The main issues occur in winter, when the internal courtyards are totally devoid of any natural daylight (Figure 7) [31]. Conversely, the analysis shows that all of the roofs are constantly exposed to the sun. For this reason, we suggest the installation of active solar energy systems.

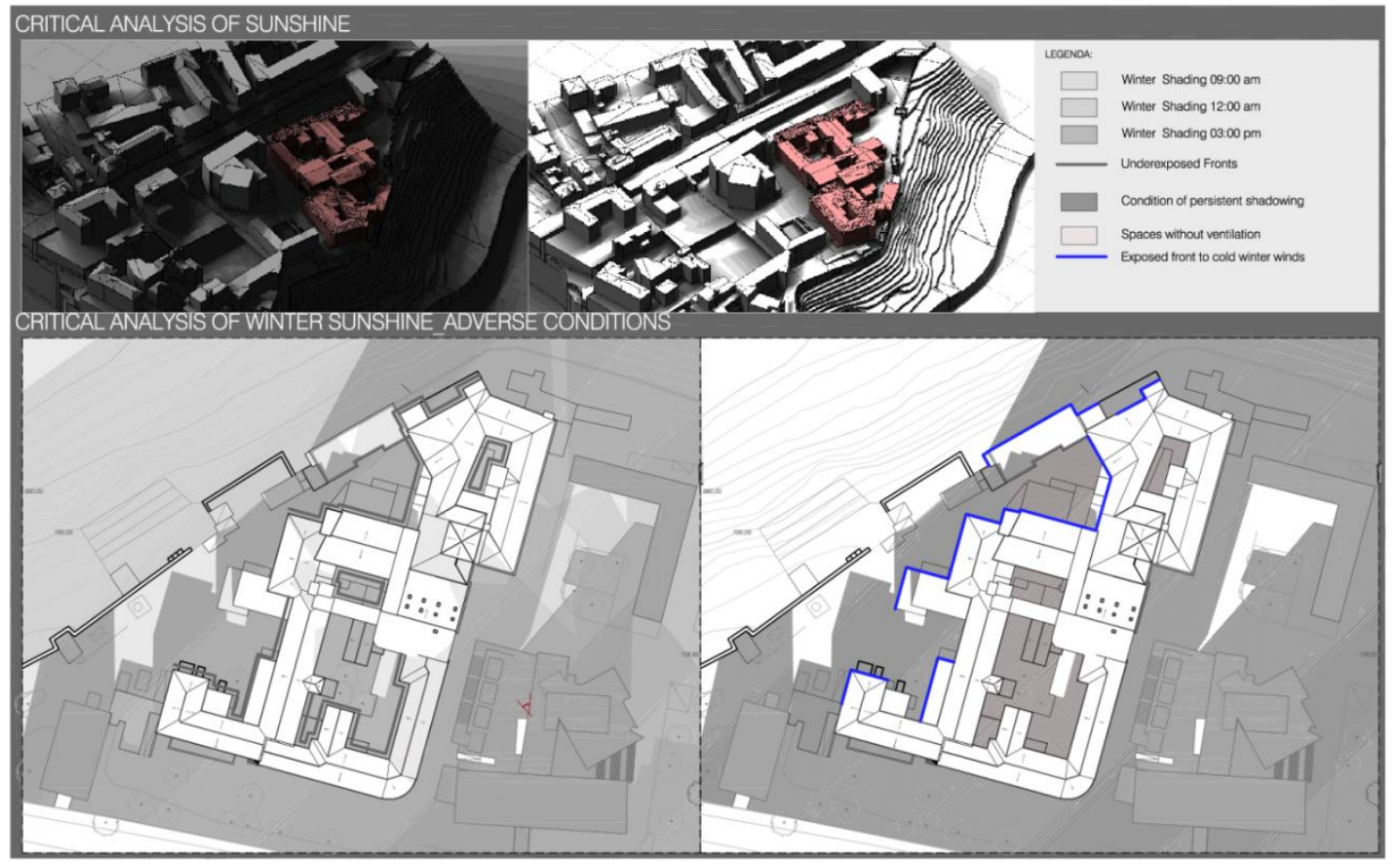

Figure 7. Solar analysis of the building.

This solution may be slightly problematic, as the response is frequently, "this option has not been properly utilized because of psycho-social barriers and lack of information" [8,32]. However, "there are worthy examples, based on meticulous research aimed at appropriate integration that demonstrate the enormous potential of integrating these elements into historical buildings" [8]. In this case, the architectonic integration of active solar energy systems is based on the principle of minimal visible impact, and installation of these units would respect the outline of the roof as well as figurative and aesthetic aspects such as color and material [33].

A quantitative analysis of the solar radiation carried out on all the surfaces of the actual building envelope and the surfaces of a simplified envelope that encloses the building (the modeling hypothesis) showed the annual trend of incident solar radiation. This analysis indicated minimal solar gains for some areas in the colder months - much lower than the available solar radiation—but higher values for some areas both in winter and in summer, (in the latter season, presumably subject to overheating) [34]. 
As shown in the picture, the surfaces exposed to the south, (southeast) have the most favorable conditions in winter, with an incident solar radiation of about $20 \%$ of the available solar radiation (around $267 \mathrm{Wh} / \mathrm{m}^{2}$ compared to $1295 \mathrm{Wh} / \mathrm{m}^{2}$ available) (Figure 8).

Finally, the analysis of the ventilation showed the prevalence of winter and summer winds blowing from the N-NW, with average speed values of about $1.1 \mathrm{~m} / \mathrm{s}$ in the various months of the year. The analysis highlighted the fact that there are facades constantly exposed to the winds, both in summer and winter. The summer breezes had a cooling effect on the front of the building. However, it also revealed that there are confined spaces with no ventilation, potentially subject to the formation of damp and unhealthy air (Figure 9).

In summary, the assessments show that most of the building complex has an inadequate energy efficiency performance and is not sufficiently exposed to the sun. In addition to this, there is a prevalence of cold winter winds on some fronts, and poor ventilation (input data provided by the Centre of Excellence for the Integration of Remote Sensing Techniques and Numerical Models for early warning of severe meteorological events (CETEMPS)), which prevents air renewal and the general improvement of thermo-hygrometric conditions.

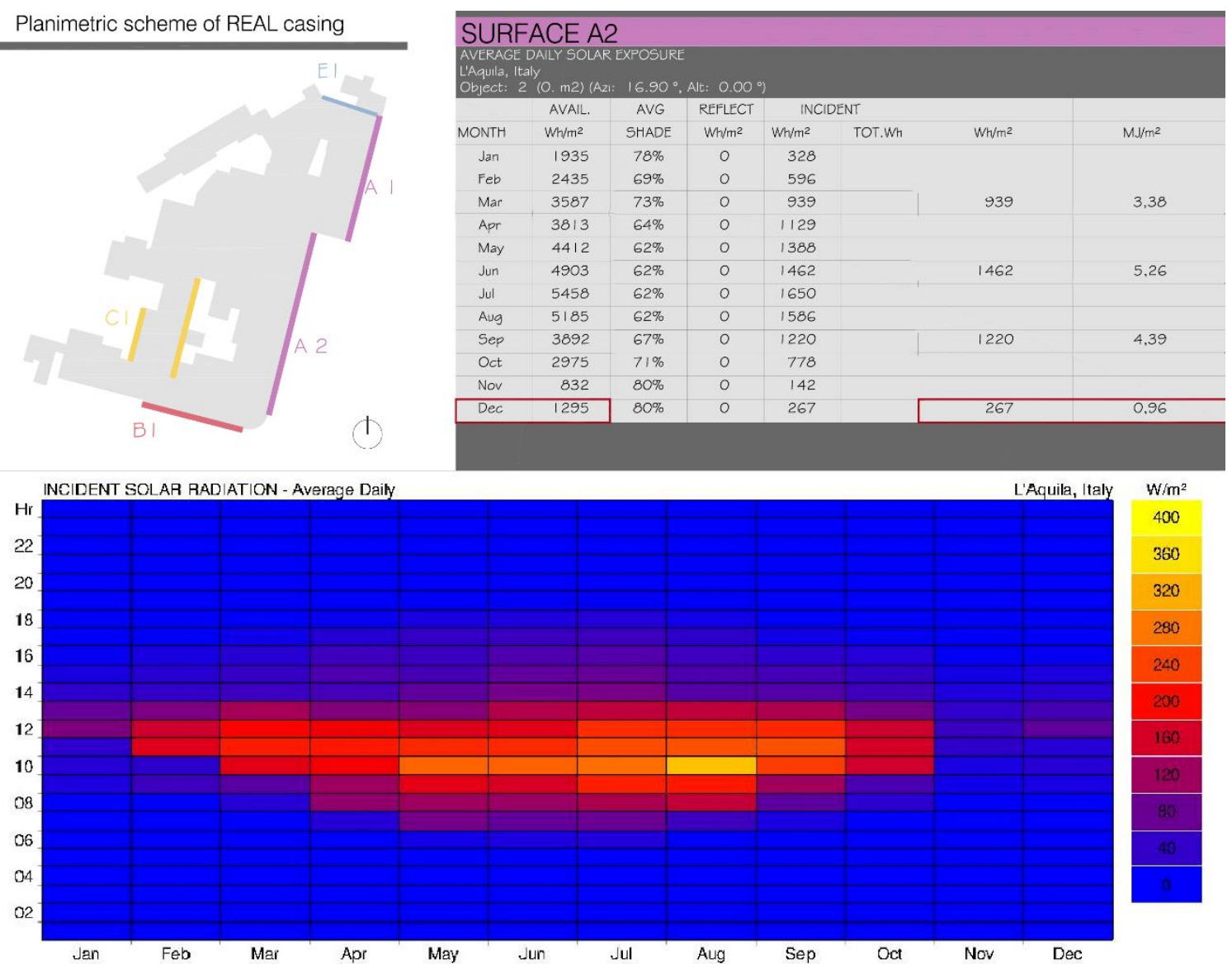

Figure 8. Solar radiation analysis. 


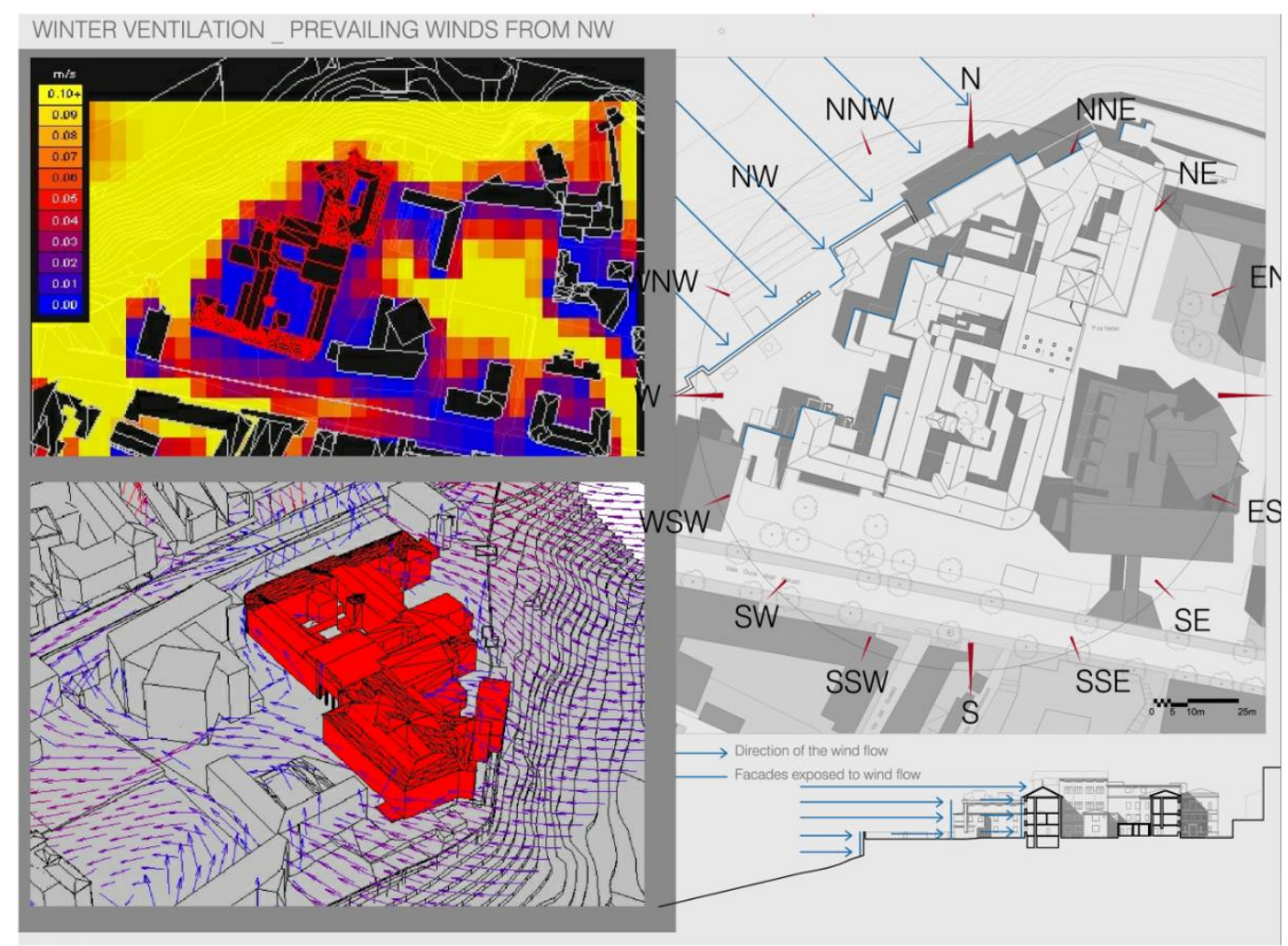

Figure 9. Ventilation analysis.

\subsection{The Project: from Intervention Strategies to Technological Insights}

The surveys carried out on the historic building highlighted the presence of historical and construction values to be preserved, but also of accretions and structural damage. These studies support our proposal to demolish all the extensions built over the years. In fact, the construction of these exterior accretions has caused substantial damage as a result of the seismic stress, with consequent deterioration of the structural conditions of the building complex. Moreover, it has led to the closure of internal courtyards, limiting considerably the penetration of natural light and ventilation. Hence, the first step of our design solution was to strip the building of all inadequate extensions and return it to its original configuration. The creation of inclusive gathering spaces and, from a functional point of view, the clearing of the courtyards, would allow an improvement of sanitary and environmental conditions while enabling better penetration of natural light and ventilation.

Once the portions of the building to be demolished had been identified, design strategies could be implemented to achieve the objectives already listed above and summarized below:

- Space re-purposing, by changing the intended use, and space re-arrangement according to modern environmental and sanitary standards;

- Upgrading of the technological system by restoring or improving the performance levels of the existing building elements, where they were affected by issues linked to technological performance; and

- Aesthetic rehabilitation of the historic building through the introduction of new design elements.

To achieve these goals, we developed a project focusing on energy efficiency upgrading, structural strengthening of the portions of the building characterized by important historical, aesthetic and architectural values, and on the re-arrangement of spaces to meet the needs of different users. The proposed design for the building, including new, partially underground spaces, retains total respect for the structural, architectural and aesthetic aspects of the original construction structure. The project of expansion, in fact, does not aim to disrupt the typical features of the building complex 
such as the courtyard building shape, and is the result of a careful study on transformability and compatibility with the pre-existing construction. What the project proposes, therefore, is an aesthetic rehabilitation of the building that is both the indirect consequence of the changes that affect the building related to other types of problems and a consequence of the need to highlight the transformation caused by the rehabilitation process itself.

In line with the city's plan to provide university residences for students, it is intended that the building of the former San Salvatore hospital, thanks to its strategic location in the heart of the city, will be transformed into an integrated university campus that supports the facilities already operating in that area, offering services both to students and citizens. Thus, our project incorporates recreational facilities, cultural facilities (libraries, exhibition areas and aggregation spaces), sports facilities and green spaces, and a flywheel for the rehabilitation and development of the urban fabric involved in the intervention [35].

The oldest section of the building complex, together with an extension built in the 1950s (north-eastern part), will comprise the university residences and related services, including a self-service bar, study rooms, lounges and meeting rooms that are also open to the general public. The university residence will have a capacity of about 100 beds, made up of single and double rooms, mini-apartments and apartment shares, and will include internal and external common areas and a communal kitchen on each floor.

The intervention to upgrade the building's energy efficiency requires, above all, the implementation of a careful compatibility check of the procedure and utilization of newly developed technologies in complex contexts, such as historical ones [36]. High levels of reliability and durability must be achieved by combining technologies consolidated over centuries with the latest high-performance products available on the market. The method consists of superimposing "dry" layers, which improve the performance levels of the building's elements, on the "wet" sedimentation, using minimally invasive and completely reversible techniques. In fact, in addition to the demolition of the roof and of the last floor due to severe structural deficiencies, the project includes the introduction of a new wooden structure inside the existing perimeter walls, which have undergone a structural consolidation, in order to improve both the building's seismic performance and the thermo-hygrometric features of the building envelope. On the second floor, in fact, the introduction of X-LAM self-supporting panels will help solve functional problems, increasing the performance and the overall functioning of the building organism as they work at a structural level, providing stiffness and resistance to the actions carried out on the floor, as well as on an energy performance level, as they can be seen as a surface addition to the treatment of a pre-existing building envelope (Figure 10) [37,38].

The existing building envelope does not meet current requirements, so our project proposes an intervention to upgrade the building to comply with current legislation on the energetic rehabilitation of historic buildings. This includes the replacement of existing windows with new windows having aluminum thermal cutting frame and double glazing, the remaking of a ventilated roof replacing the old one, and the installation of a cladding system with internal and external insulation.

The analysis of the lighting levels inside the rooms carried out using Design Builder software highlighted the uneven distribution of daylight. For this reason, the installation of lightshelves and heliostats is included to ensure homogeneous illuminance values.

Further technological expedients used to achieve energy autonomy includes interventions on the building's energy plant system, such as the integration of photovoltaic panels and elements to transport, control and use natural light to reach a high level of indoor illumination and adequate climatic and thermo-hygrometric design of open spaces.

The study also looked at insulation solutions, compatible with the building, both from an aesthetic as well as performance point of view, able to solve the critical winter issues with the building envelope, in particular the vertical closures, without compromising its efficiency during the summer. 


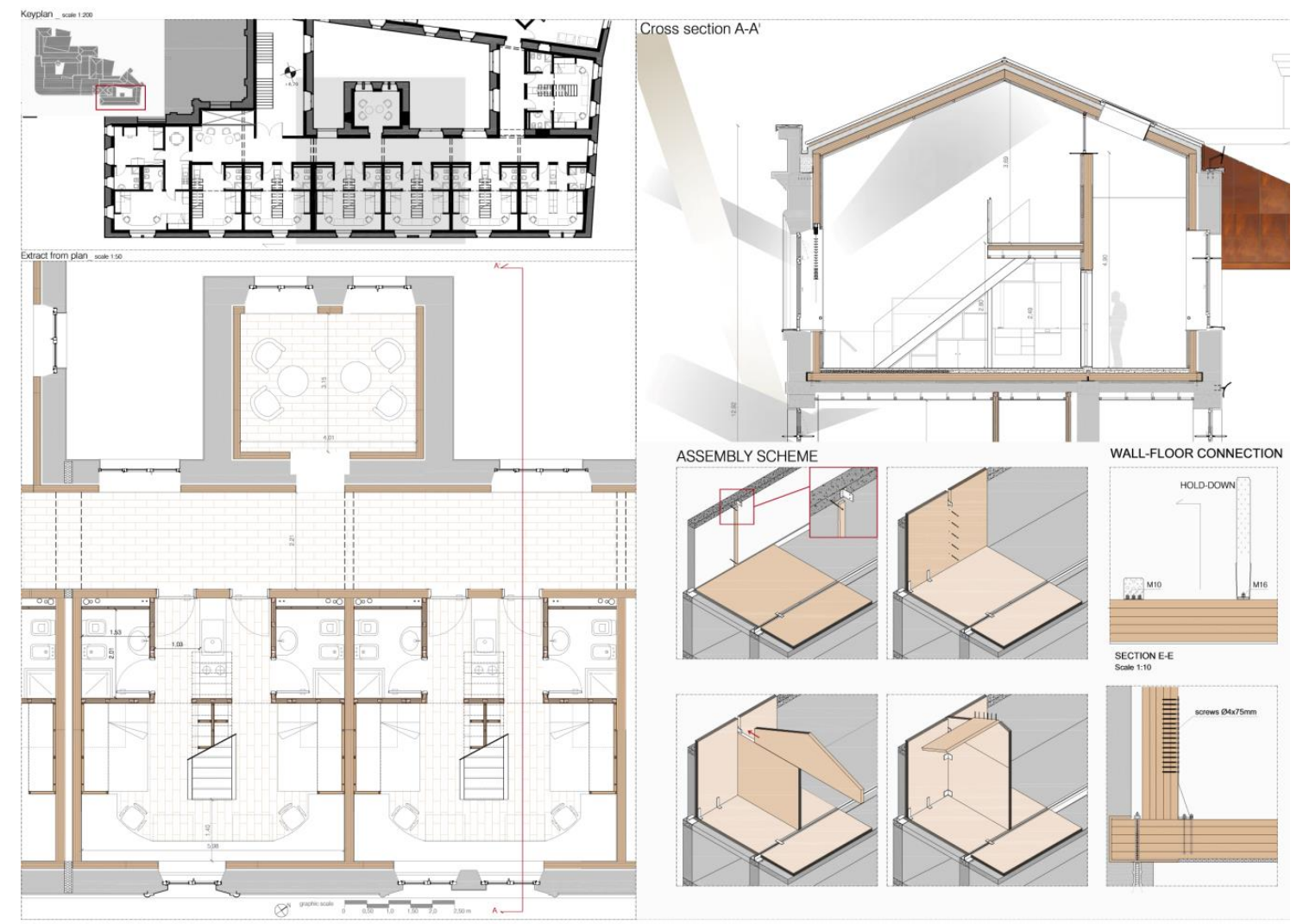

Figure 10. The new wooden structure adjacent to the pre-existing building.

Clearly, these solutions must ensure adequate compatibility levels with the history, aesthetic layout and behavior of the existing structure. Hence, the idea of applying only an external insulation coating was excluded, because it would have resulted in thickness impacting on a building of this type. Likewise, the solution of applying only an internal insulation coating was also rejected, because most of the thermo-hygrometric assessments showed that the values of the interstitial condensation were not met. Furthermore, from an architectural point of view, this solution would have resulted in a reduction of internal spaces. Therefore, the most suitable solution, able to meet both the performance and aesthetic requirements, is the use of internal-external insulation coating.

The insulation materials that can be used are of different types: mineral, vegetable, animal and/or synthetic [39]. The choice of insulation can be made with the help of a series of post-intervention dynamic simulations carried out with Design Builder software, which shows, for each type of insulation used, parameterized output data that can be used to identify an optimal choice. The results obtained using the dynamic simulations performed for each compatible solution are shown in Figure 11. The table shows thickness, heating and cooling needs, costs and thermo-hygrometric analysis of the various solutions examined and gains achieved compared to the current state. The results reveal that, in very similar conditions of transmittance, the increase in the heating needs in winter are almost the same for the various types of insulation [4].

In the warmer months, there is an increase of the internal temperature, which exceeds $25^{\circ} \mathrm{C}$; for this reason, the cooling requirement increases, to maintain adequate levels of indoor comfort. This increase of the cooling requirement in percentage is very similar for all the solutions; therefore, thickness, cost and hygrometric check were the key parameters in the final choice. 


\begin{tabular}{|l|c|c|c|c|}
\hline & WALL THICKNESS $(\mathrm{cm})$ & TRANSMITTANCE $(\mathrm{W} / \mathrm{mqK})$ & $\begin{array}{c}\text { HEATING DEMAND } \\
(\mathrm{KWh} / \mathrm{mq})\end{array}$ & $\begin{array}{c}\text { COOLING DEMAND } \\
(\mathrm{KWh} / \mathrm{mq})\end{array}$ \\
\hline Current state & 60 & 1.052 & 90.14 & 6.16 \\
\hline
\end{tabular}

\begin{tabular}{|c|c|c|c|c|c|c|c|c|}
\hline \multirow{3}{*}{$\begin{array}{c}\text { INTE RVENTION } \\
\begin{array}{c}\text { Intemal/external } \\
\text { insulation }\end{array}\end{array}$} & \multirow{2}{*}{\begin{tabular}{|l|} 
INSULATION TYPES \\
Cellulose fiber-aerogel
\end{tabular}} & \multicolumn{2}{|c|}{ THICKNESS(cm) } & \multicolumn{2}{|c|}{ TRANSMITTANCE (W/mqK) } & \multicolumn{2}{|c|}{ HEATING DEMAND $(\mathrm{KWh} / \mathrm{mq})$} & \multirow{2}{*}{$\begin{array}{c}\text { REDUCTION OF HEATING } \\
\text { DEMAND }(\%)\end{array}$} \\
\hline & & $10+1.5$ & $\circ$ & 0.27 & ${ }^{\circ}$ & 43.19 & $\infty$ & \\
\hline & 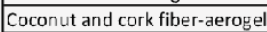 & $10+1.5$ & $\circ$ & 0.264 & so & 43.12 & $\infty$ & 52,16 \\
\hline & Kenaf fiber-aerogel & $8+1.5$ & $\circ$ & 0.259 & 00 & 42.96 & 000 & 52,34 \\
\hline Cappotto Irt.-Est. & Mais fiber-aerogel & $7+1,5$ & ooc & 0.252 & $\infty$ & 42.73 & 000 & 52.6 \\
\hline \multirow{4}{*}{$\mathrm{F}$} & Wood fiber-aerogel & $7+1.5$ & 000 & 0.257 & 00 & 43.01 & $\circ$ & 52.28 \\
\hline & Sheep wool - aerogel & $9+1.5$ & $\circ$ & 0.269 & ${ }^{\circ 0}$ & 43.15 & $\circ$ & 52.13 \\
\hline & Rock wool-aerogel & $8+1.5$ & $\circ$ & 0.259 & ${ }^{\circ 0}$ & 42.84 & 000 & 52.47 \\
\hline & PET-aerogel & $7+1.5$ & ${ }^{000}$ & 0.266 & 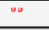 & 42.97 & 000 & 52.33 \\
\hline \multirow{4}{*}{ 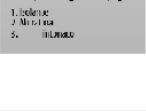 } & EPS foam-aerogel & $9+1.5$ & $\cdots$ & 0.253 & $\infty$ & 43.05 & $\infty$ & 52.24 \\
\hline & Blond cork -aerogel & $8+1.5$ & $\cdots$ & 0.27 & $\circ$ & 43.15 & $\cdots$ & 52.13 \\
\hline & Wood wool-aerogel & $12+1.5$ & ${ }^{\circ}$ & 0.258 & $\circ$ & 42.89 & $\cdots$ & 52.41 \\
\hline & Cellular Glass ins.-aerogel & $9+1.5$ & 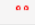 & 0.253 & as & 43.08 & $\infty$ & 52.21 \\
\hline
\end{tabular}

\begin{tabular}{|c|c|c|c|c|c|c|c|c|}
\hline \multirow{3}{*}{$\begin{array}{c}\text { INTERVENTION } \\
\begin{array}{c}\text { Intemalexternal } \\
\text { insulation }\end{array}\end{array}$} & \multirow{2}{*}{\begin{tabular}{|l|} 
INSULATION TYPES \\
Cellulose fiber-aerogel
\end{tabular}} & \multirow{2}{*}{$\begin{array}{c}\text { COOLING DEMAND } \\
\text { (KWh/mq) }\end{array}$} & \multicolumn{2}{|c|}{$\begin{array}{l}\text { INCREASE OF COOLING DEMAND } \\
(\%)\end{array}$} & \multicolumn{2}{|c|}{$\cos T$ (euro/mq) } & \multicolumn{2}{|c|}{ SURFACE /INTERSTITIAL MOISTURE } \\
\hline & & & 34.31 & 0 & 159,12 & $\circ$ & TT EVAPORATES IN SUMM MER NONTHS & 0 \\
\hline & Coconut and cork fiber-aerogel & 9.38 & 34.32 & ${ }^{\circ}$ & 184.91 & ${ }^{\circ}$ & T EVAPORATES IN SUM MER NONTHS & ${ }^{\circ}$ \\
\hline & Kenaf fiber-aerogel & 9.36 & 34.19 & $\circ$ & 117.78 & 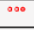 & TEVAPORATES IN SUM MER NONTHS & 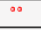 \\
\hline Cappotto Int.-Est. & Mais fiber-aerogel & 9.36 & 34.19 & $a$ & 134.26 & ${ }^{\mathrm{a} a}$ & ABSENT & 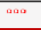 \\
\hline \multirow{4}{*}{ IF } & Wood fiber-aerogel & 9.28 & 33.62 & $\because$ & 116.6 & 000 & ABSENT & $\cdots$ \\
\hline & Sheep wool - aerogel & 9.41 & 34.54 & ${ }^{\circ}$ & 98.93 & 000 & TT EVAPORATES IN SUM MER NONTHS & ${ }^{\circ}$ \\
\hline & Rock wool-aerogel & 9.33 & 33.97 & . & 117.78 & 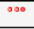 & TT EVAPORATES IN SUM MER NONTHS & $\cdots$ \\
\hline & \begin{tabular}{|l|} 
PET-aerogel \\
\end{tabular} & 9.35 & 34.12 & $\circ$ & 128.38 & $\therefore$ & ABSENT & 000 \\
\hline \multirow{4}{*}{ 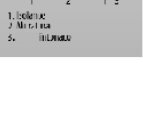 } & EPS foam-aerogel & 9.33 & 33.97 & $\%$ & 114.24 & 200 & TT EVAPORATES IN SUNM MER NONTHS & $\circ$ \\
\hline & Blond cork -aerogel & 9.32 & 33.91 & ○ & 176.67 & $\cdot$ & ABSENT & $\cdots$ \\
\hline & Wood wool-aerogel & 9.26 & 33.48 & $\circ$ & 117.8 & 000 & ABSENT & 000 \\
\hline & \begin{tabular}{|l} 
Cellular Glass ins.-aerogel \\
\end{tabular} & 9.33 & 33.97 & 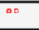 & 123.67 & ${ }^{a a}$ & ABSENT & 2 aمa \\
\hline
\end{tabular}

Figure 11. Comparison of the performance of different types of insulation.

The following types of wall insulation were identified for this project:

- insulating panels and aerogel-based plasters with reduced thickness (about $1.5 \mathrm{~cm}$ ), given their high thermal resistance, for the external coating for the portion of the building characterized by the presence of stone jambs and frames on the windows, which do not allow the use of high-thickness insulating panels; and

- panels in wood pressed fibers for the inner coat, in adherence to the perimeter masonry walls, $7 \mathrm{~cm}$ thick. Such material, besides being natural, eco-friendly, recyclable and biodegradable due to its vegetal origin, allows for the use of a reduced thickness, which is essential to preserve the size of the internal spaces $[40,41]$.

Lastly, insulating panels in granular expanded glass were chosen for the roof also because of their high mechanical resistance to compression, which is an important factor, given the installation on the roof of photovoltaic panels integrated in the coating, which need proper support.

\section{Discussion: Assessment of the Improvement Levels Predicted to Be Achieved}

The steady-state assessments of all the envelope elements at the design stage show a significant improvement in both the transmittance values and phase shift values of the thermal wave. For the horizontal closures, there is a U-value of $0.19 \mathrm{~W} / \mathrm{m}^{2} \mathrm{~K}$ and a phase shift value of $10 \mathrm{~h}$, while the vertical closures have a U-value of $0.25 \mathrm{~W} / \mathrm{m}^{2} \mathrm{~K}$ and a phase shift equal to $5 \mathrm{~h}$, which are perfectly within the limits imposed by law, as are the superficial and interstitial condensation values (Figure 12). 


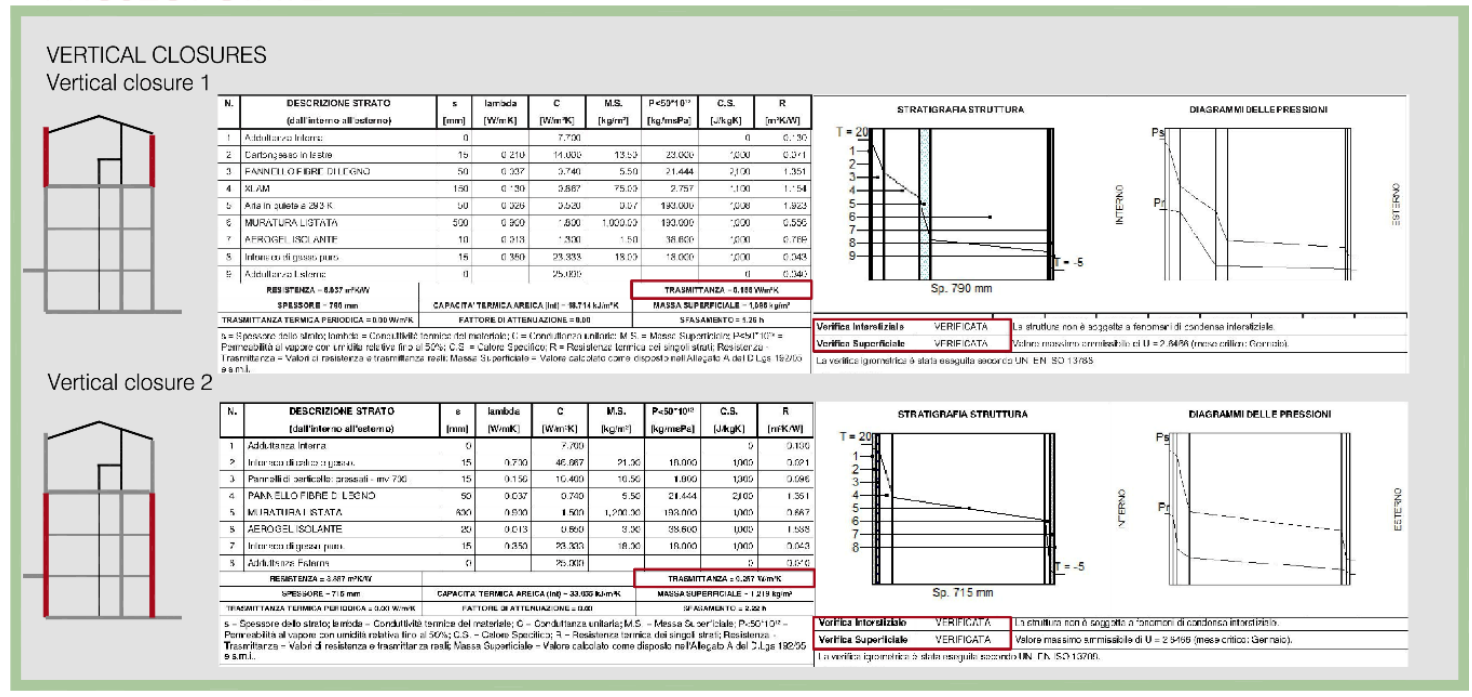

Figure 12. Thermal analysis of the walls in steady regime, project state.

Similarly, the assessments in dynamic state, carried out with Design Builder software, show a significant gain on winter thermal loads, with a reduction of the heating needs of approximately $52.28 \%$ (value of about $43,016 \mathrm{Wh} / \mathrm{m}^{2}$ ) and a reduction in the relative indoor humidity value, although there is a slight temperature increase during the month of August, to approximately $25.10^{\circ} \mathrm{C}$, compared to the $24.70^{\circ} \mathrm{C}$ of the current state (Figures 13 and 14). This aspect is negligible compared to the considerable reduction in winter heating demand (Figure 15).

The bioclimatic analyses show, as previously mentioned, that the roof pitches of the building are permanently exposed to the sun (Figure 16). Such data supports the idea of installing systems able to exploit renewable energy [42], also taking into account the considerable annual energy requirements of the portion of the building used as a residence equal to $223,818.90 \mathrm{kWh} / \mathrm{yr}$. Two types of photovoltaic modules are suitable, depending on the orientation and inclination of the roof:

- $\quad$ single-crystal silicon modules integrated into the glass for the flat glass roof, with a peak power of $147 \mathrm{Wp} / \mathrm{m}^{2}$ and a $17 \%$ efficiency;

- flexible thin-film modules installed on the coating of the pitched roofs with east-west orientation, with a nominal power of $68 \mathrm{Wp} / \mathrm{m}^{2}$ and a $10 \%$ efficiency (Figure 17) [8].

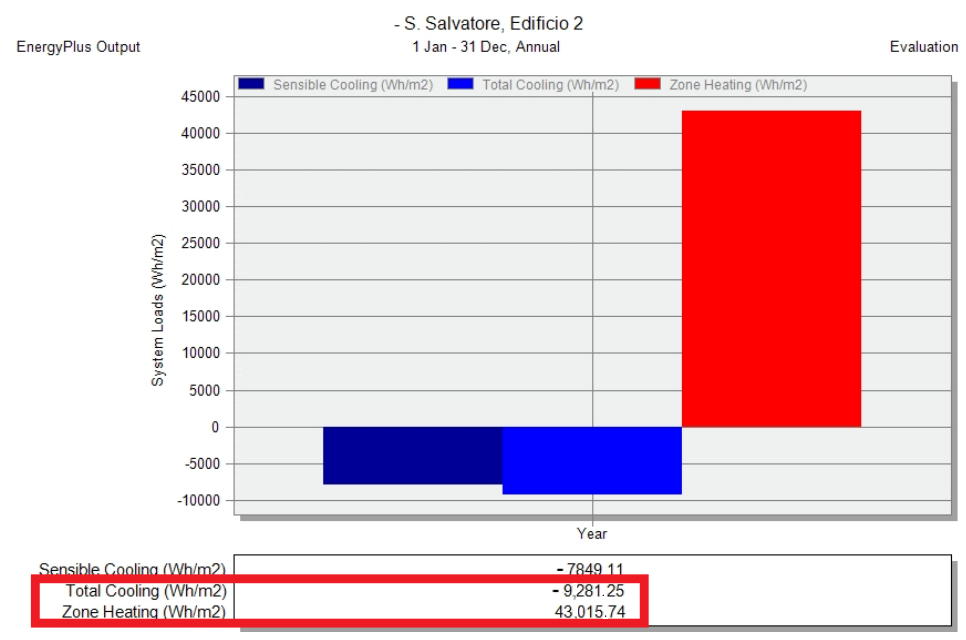

Figure 13. Total consumption of the building in dynamic regime, project state. 


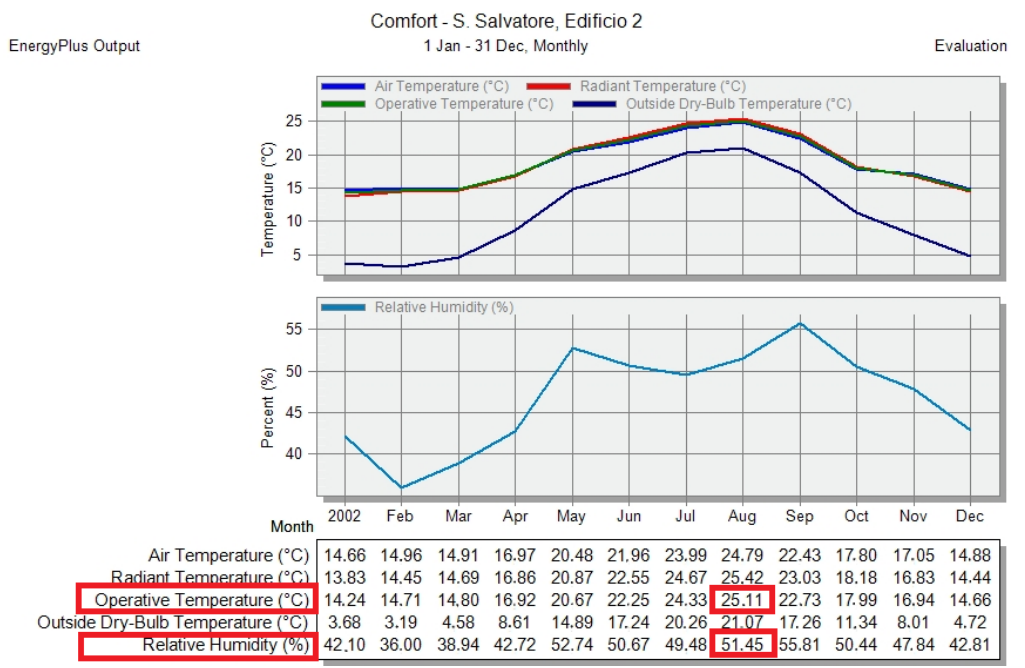

Figure 14. Monthly comfort curve, project state.

\begin{tabular}{|c|c|c|c|c|c|c|c|c|}
\hline & $\begin{array}{c}\text { WALL } \\
\text { THICKNESS } \\
(\mathrm{cm})\end{array}$ & $\begin{array}{c}\text { TRANSMITTANCE } \\
(\mathrm{W} / \mathrm{mqK})\end{array}$ & $\begin{array}{c}\text { HEATING } \\
\text { DEMAND } \\
(\mathrm{KWh} / \mathrm{mq})\end{array}$ & $\begin{array}{c}\text { COOLING } \\
\text { DEMAND } \\
(\mathrm{KWh} / \mathrm{mq})\end{array}$ & $\begin{array}{c}\text { OPERATIVE } \\
\text { TEMPERATURE } \\
\text { IN SUMMER }\left({ }^{\circ} \mathrm{C}\right)\end{array}$ & $\begin{array}{c}\text { RELATIVE } \\
\text { HUMIDITY IN } \\
\text { SUMMER (\%) }\end{array}$ & $\begin{array}{c}\text { OPERATIVE } \\
\text { TEMPERATURE } \\
\text { IN WINTER }\left({ }^{\circ} \mathrm{C}\right)\end{array}$ & $\begin{array}{c}\text { RELATIVE } \\
\text { HUMIDITY IN } \\
\text { WINTER (\%) }\end{array}$ \\
\hline $\begin{array}{c}\text { CURRENT } \\
\text { STATE }\end{array}$ & 60.00 & 1.052 & 90.14 & 6.16 & 24.72 & 52.47 & 12.83 & 43.35 \\
\hline $\begin{array}{c}\text { PROJECT } \\
\text { STATE }\end{array}$ & 68.50 & 0.257 & 43.01 & 9.28 & 25.11 & 51.45 & 14.24 & 42.10 \\
\hline
\end{tabular}

Figure 15. Comparison between the energy requirements of the chosen solution and the current state.

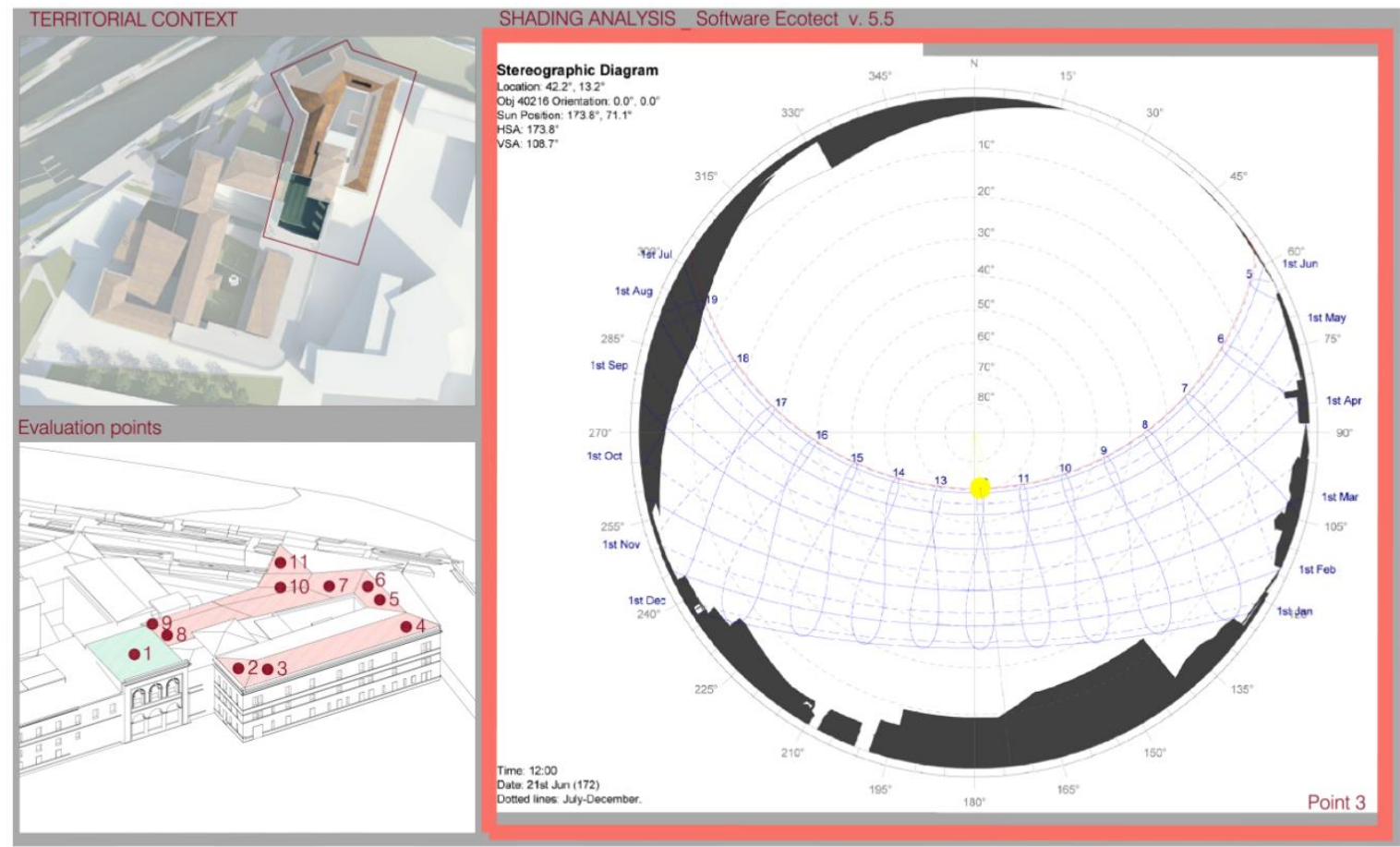

Figure 16. Sun path and shadows on the roof: stereographic diagram. 


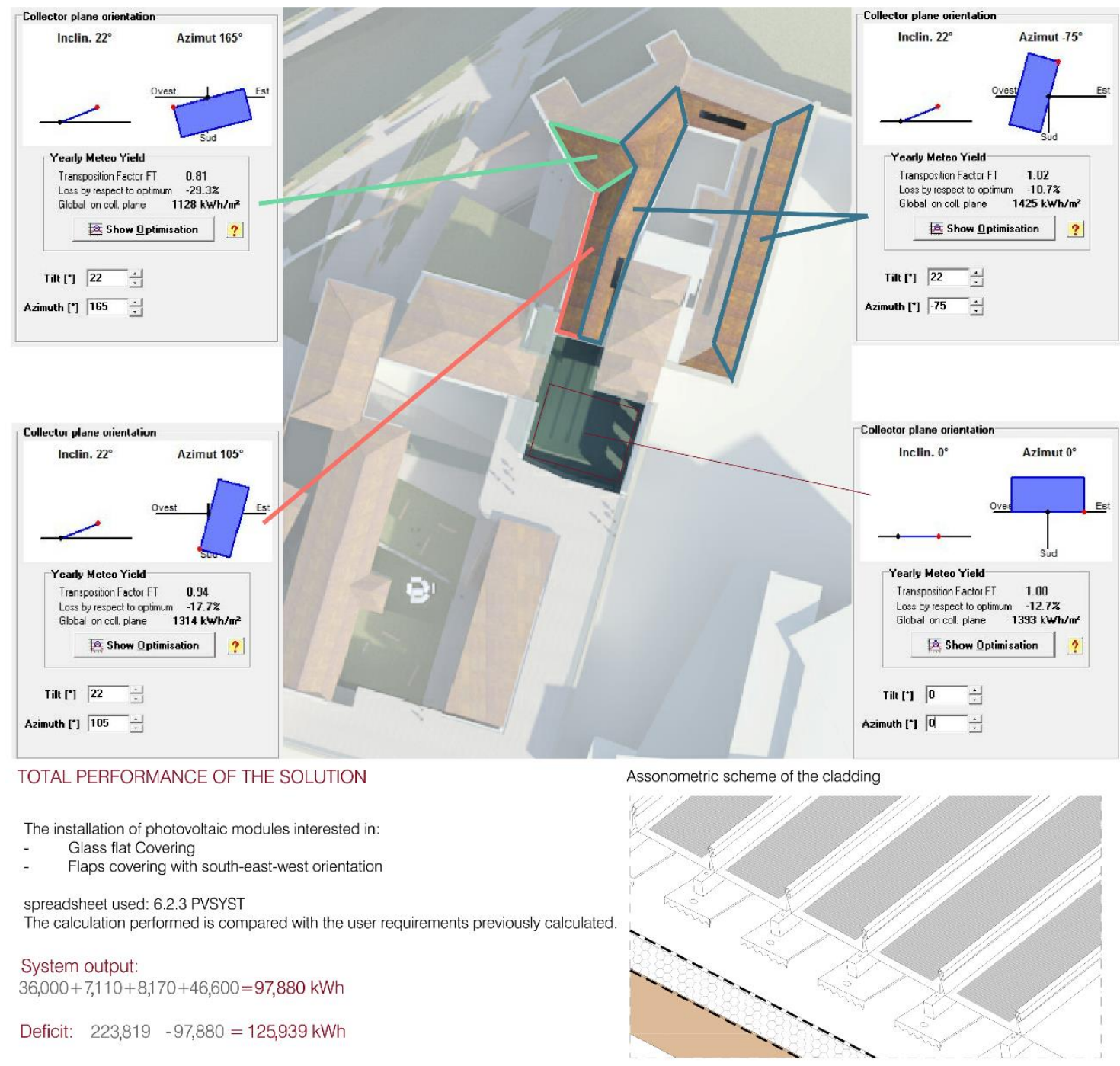

Figure 17. Photovoltaic modules installed on the roof.

The roof-integrated photovoltaic systems generate about $98,000.00 \mathrm{kWh} / \mathrm{yr}$ of energy, equal to approximately $33 \%$ of the electric energy requirements previously calculated.

\section{Conclusions}

The research illustrated in this paper shows irrefutably the importance of the process of analysis, not only of the formal, material and cultural-historical aspects of a building and its context, but also of the functional and performance behavior of the building elements, in order to achieve a complete and comprehensive characterization of the building elements based on the interconnecting of varying analyses (thermographic, thermo-hygrometric and heat-flux analysis) (Figure 18) [30].

The second important aspect that has emerged from this study is related to the use of newly developed technologies to implement regeneration and requalification. Technological innovation can provide means of dealing with the difficulties of combining the preservation of architectural and morphological values of the building constructions with the new needs of contemporary living as well as compliance with current standards and legislation. In addition, historical buildings, mostly built in compliance with "art rules" with regards to materials and technical aspects, fare better with the introduction of soft technologies, like innovative ones, aimed at integrating rather than replacing. 

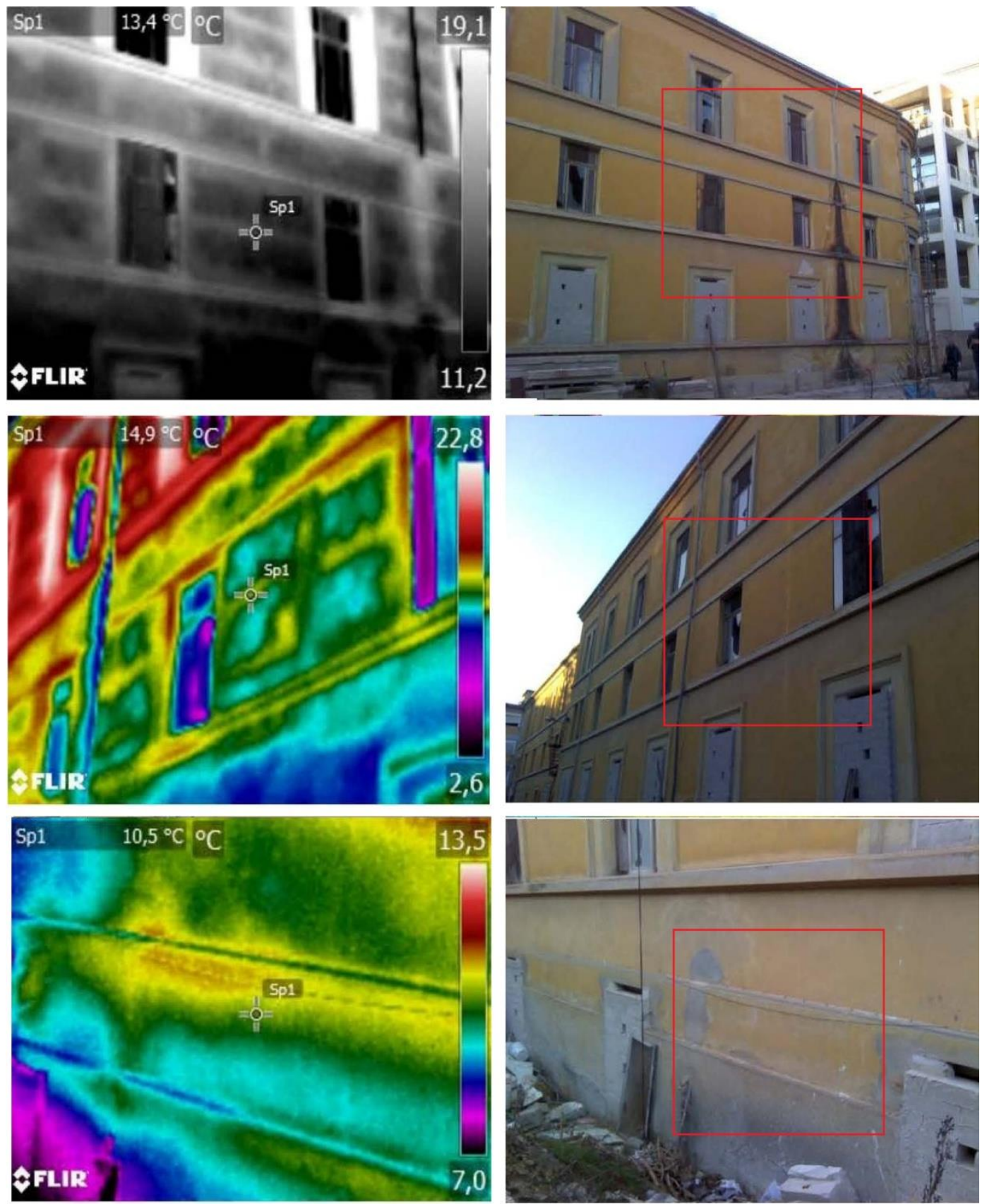

Figure 18. Thermographic diagnosis of the Building.

Finally, intervention on historical buildings should be considered and treated as a unique opportunity, not easily transferable to other cases. Work on pre-existing structures and changing the behavior of elements originating in different historical and cultural contexts must be implemented through accurate and localized actions rather than repetitive and universal ones. Therefore, we reaffirm the need for specific, single interventions, and encourage specific rehabilitation projects, as they are the only effective means of responding to the diversity and uniqueness of different contexts (Figure 19).

There is no single solution, since the most effective solution is to "test" the many opportunities that arise and, in most cases, literally invent the technical-executive procedure best suited to the historical context and to the specific features of the overall and individual form of the building. The only replicability resides in the orientation of the method that is based on the synergistic arrangement of the critical analysis of the building, climatic analysis and evaluation of environmental 
comfort. Therefore, it is necessary to start with a thorough analysis of the structure and the typological and technical-construction aspects of the original "building-container", aimed at the critical acknowledgement of the values and its technical and cultural transformability. Not forgetting, lastly, to introduce climatic analysis into the conceptual system, which is essential for the proper elaboration of design strategies aimed at upgrading and improving environmental comfort.

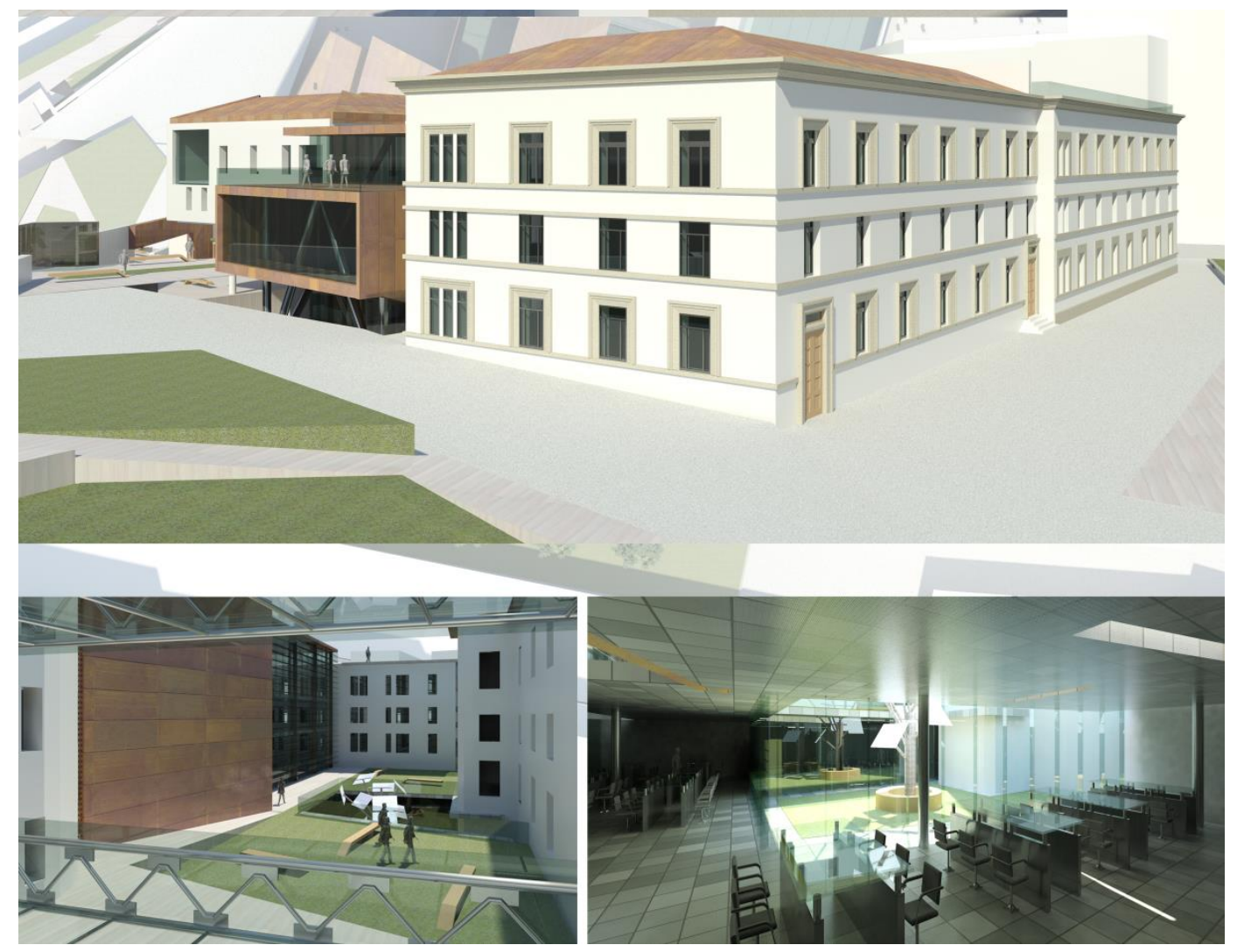

Figure 19. Photorealistic rendering of the new added volumes.

Author Contributions: Pierluigi de Berardinis, was responsible for the scientific research; Marianna Rotilio and Pierluigi de Berardinis conceived and designed the experiments and the methodology; Luisa Capannolo performed the experiments, analyzed the data and realized all the figures; Pierluigi de Berardinis, Marianna Rotilio and Luisa Capannolo wrote the paper.

Conflicts of Interest: The authors declare no conflict of interest.

\section{References}

1. Legambiente Basta Case Vuote di Carta, Dossier. May 2014. Available online: https://www.legambiente.it/ sites/default/files/docs/dossier_stopconsumodisuolo_maggio2014.pdf (accessed on 18 August 2017).

2. De la Cruz-Lovera, C.; Perea-Moreno, A.J.; de la Cruz-Fernández, J.L.; Alvarez-Bermejo, J.A. Worldwide Research on Energy Efficiency and Sustainability in Public Buildings. Sustainability 2017, 9, 1294. [CrossRef]

3. Rotilio, M.; De Berardinis, P.; Cucchiella, F. Renewable Energy Sources in Minor Historical Centers. New Scenarios of Sustainable Development of the Territory. In Sustainable Future Energy Technology and Supply Chains a Multi-Perspective Analysis; Cucchiella, F., Koh, L., Eds.; Springer International Publishing: Basel, Switzerland, 2015; pp. 75-106, ISBN 978-3-319-02695-4.

4. El-Darwish, I.; Gomaa, M. Retrofitting strategy for building envelopes to achieve energy efficiency. Alexandria Eng. J. 2017, in press. [CrossRef]

5. Han, F.; Yang, Z.; Shi, H.; Liu, Q.; Wall, G. How to Promote Sustainable Relationships between Heritage Conservation and Community, Based on a Survey. Sustainability 2016, 8, 886. [CrossRef] 
6. Semprini, G.; Marinosci, C.; Ferrante, A.; Predari, G.; Mochi, G.; Garai, M.; Gulli, R. Energy management in public institutional and educational buildings: The case of the school of engineering and architecture in bologna. Energy Build. 2016, 126, 365-374. [CrossRef]

7. UE. Politica Energetica Para Europa. Plan de Acción del Consejo Europeo. Brussels. Available online: http:/ / ec.europa.eu/index_en.htm (accessed on 13 February 2017).

8. Polo López, C.S.; Frontini, F. Energy Efficiency and Renewable Solar Energy Integration in Heritage Historic Buildings. Energy Procedia 2014, 48, 1493-1502. [CrossRef]

9. Basarir, B.; Diri, B.S.; Diri, C. Energy Efficient Retrofit Methods at the Building Envelopes of the School Buildings. 2016. Available online: http:/ /www.academia.edu/1844159/Energy_efficient_retrofit_methods_ at_the_building_envelopes_of_the_school_buildings (accessed on 18 August 2017).

10. De Berardinis, P.; Rotilio, M.; Marchionni, C.; Friedman, A. Improving the energy-efficiency of historic masonry buildings. A case study: A minor centre in the Abruzzo region, Italy. Energy Build. 2014, 80, 415-423. [CrossRef]

11. Pecchioni, E.; Santo, A.P.; Piccini, L.; Di Fazio, L.; Fratini, F.; Pallecchi, P.; Trevisan, R.; Garzonio, C.A. The Vie Cave Geomorphological Site in Southern Tuscany (Italy): Problems of Decay and Conservation. Sustainability 2015, 7, 7530-7547. [CrossRef]

12. Dukanovic, D. Dialog between contemporary perspectives and conservation principles. In Rehab 2017; Amoeda, R., Lira, S., Pinheiro, C., Eds.; Green Lines Institute for Sustainable Development: Barcelos, Portugal, 2017; pp. 243-253, ISBN 978-989-8734-24-2.

13. Zamperini, E.; Morandotti, M.; Cinieri, V.; Lucenti, S. From knowledge to management. Methods and tools for the planned conservation of university built heritage. A case study. In Rehab 2017; Amoeda, R., Lira, S., Pinheiro, C., Eds.; Green Lines Institute for Sustainable Development: Barcelos, Portugal, 2017; pp. 487-496, ISBN 978-989-8734-24-2.

14. Martínez-Molina, A.; Tort-Ausina, I.; Cho, S.; Vivancos, J.-L. Energy efficiency and thermal comfort in historic buildings: A review. Renew. Sustain. Energy Rev. 2016, 61, 70-85. [CrossRef]

15. Cucchiella, F.; De Berardinis, P.; Koh, S.C.L.; Rotilio, M. Planning restoration of a historical landscape: A case study for integrating a sustainable street lighting system with conservation of historical values. J. Clean. Prod. 2017, 165, 579-588. [CrossRef]

16. Pacheco-Torgal, F.; Granqvist, C.-G.; Jelle, B.P.; Vanoli, G.P.; Bianco, N.; Kurnitski, J. Cost-Effective Energy Efficient Building Retrofitting, 1st ed.; Woodhead Publishing Series in Civil and Structural Engineering; Elsevier: Sawston, Cambridge, UK, 2017; ISBN 9780081011287.

17. Evangelisti, L.; Guattari, C.; Gori, P. Energy Retrofit Strategies for Residential Building Envelopes: An Italian Case Study of an Early-50s Building. Sustainability 2015, 7, 10445-10460. [CrossRef]

18. Miano, P.; Coppolino, F. The Incurables Hospital complex in the Ancient Centre of Naples: A project between layers. In Rehab 2017; Amoeda, R., Lira, S., Pinheiro, C., Eds.; Green Lines Institute for Sustainable Development: Barcelos, Portugal, 2017; pp. 343-353, ISBN 978-989-8734-24-2.

19. Montoya, F.G.; Peña-García, A.; Juaidi, A.; Manzano-Agugliaro, F. Indoor Lighting Techniques: An overview of evolution and new trends for energy saving. Energy Build. 2017, 140, 50-60. [CrossRef]

20. AlFaris, F.; Juaidi, A.; Manzano-Agugliaro, F. Improvement of efficiency through an energy management program as a sustainable practice in schools. J. Clean. Prod. 2016, 135, 794-805. [CrossRef]

21. Crawley, D.B.; Lawrie, L.K.; Pedersen, C.O.; Liesen, R.J.; Fisher, D.E.; Strand, R.K.; Taylor, R.D.; Winkelmann, R.C.; Buhl, W.F.; Huang, Y.J.; et al. EnergyPlus: A New Generation, Building Energy Simulation Program. In Proceedings of the 6th International IBPSA Conference, Kyoto, Japan, 13-15 September 1999; Volume 1, pp. 81-88.

22. Attia, S. State of the Art of Existing Early Design Simulation Tools for Net Zero Energy Buildings: A Comparison of Ten Tools, Technical Report, Architecture et Climat, Louvain La Neuve: Université catholique de Louvain. 2011. Available online: http:/ /www-climat.arch.ucl.ac.be/s_attia/attia_nzeb_tools_ report.pdf (accessed on 18 August 2017).

23. Attia, S.G.; De Herde, A. Early design simulation tools for net zero energy buildings: A comparison of ten tools. In Proceedings of the 12th Conference of International Building Performance Simulation Association, Sidney, Australia, 14-16 November 2011. Available online: https:/ /www.researchgate.net/publication/ 267947185_Early_design_simulation_tools_for_net_zero_energy_buildings_A_comparison_of_ten_tools (accessed on 18 August 2017). 
24. Tronchin, L.; Fabbri, K. Energy performance building evaluation in Mediterranean countries: Comparison between software simulations and operating rating simulation. Energy Build. 2007, 40, 1176-1187. [CrossRef]

25. Tozzi, A. L'Ospedale San Salvatore dell'Aquila nel Passato e nel Presente; Tip. F.lli Centofanti: L'Aquila, Italy, 1956.

26. Guarino, M.; Vittorini, M. Studi Preparatori per la Realizzazione di un Centro Ospedaliero a L'Aquila; Alterocca: Terni, Italy, 1968.

27. Stockel, G. La Città dell' Aquila; Gallo Cedrone: L'Aquila, Italy, 1981.

28. Centofanti, M. L'Aquila 1753-1983: Il Restauro Della Città; Colacchi: L'Aquila, Italy, 1984.

29. Centofanti, M.; Brusaporci, S. Il disegno della città e le sue trasformazioni. Città e Storia 2011, 1, $151-187$. [CrossRef]

30. Balaras, C.A.; Argiriou, A.A. Infrared thermography for building diagnostics. Energy Build. 2002, 34, 171-183. [CrossRef]

31. Sala, M. Recupero Edilizio e Bioclimatica: Strumenti, Tecniche e Casi di Studio; Esselibri: Napoli, Italy, 2001; ISBN 88-513-0004-6.

32. Scognamiglio, A.; Berni, A.; Frontini, F.; Polo Lopez, C.; Maturi, L. The Complex Dialogue Between Photovoltaics and Pre-Existing: Starting Point for a Discussion. In Proceedings of the 27th European Photovoltaic Solar Energy Conference and Exhibition, Frankfurt, Germany, 24-28 September 2012.

33. Lucchi, E.; Tabak, M.; Carì, V.; Perna, M. BiPV and Historic Buildings: A Possible Integration? Available online: https://www.researchgate.net/publication/311846558_BiPV_ed_edifici_storici_l'integrazione_e_ possibile_BiPV_and_historic_buildings_a_possible_integration (accessed on 31 July 2017).

34. Shoubi, M.V.; Bagchi, A.; Barough, A.S. Reducing the operational energy demand in buildings using building information modeling tools and sustainability approaches. Ain Shams Eng. J. 2015, 6, 41-55. [CrossRef]

35. De Berardinis, P.; Capannolo, L.; Marchionni, C. Sustainable and energy efficient rehabilitation of the former hospital of San Salvatore in L'Aquila. In Structural Studies, Repairs and Maintenance of Heritage Architecture XIV; Brebbia, C.A., Hernández, S., Eds.; Volume 153 of WIT Transactions on the Built Environment; WIT Press: Southampton, UK; Boston, MA, USA, 2015; pp. 171-182.

36. De Berardinis, P. Costruire sostenibile. L'industria delle Costruzioni 2007, 393, 4-21.

37. Capuano, L. Il Progetto di Recupero dei Centri Storici: Un Caso di Studio Rosciolo dei Marsi. Quaderni di Dottorato; Università di Pavia, Dipartimento di Ingegneria e del Territorio: Pavia, Italy, 2008; Volume 3.

38. Imperadori, M. Costruire sul Costruito; Carocci Editore: Roma, Italy, 2001; ISBN 9788843018734.

39. Jin, Q.; Favoino, F.; Overend, M. Design and control optimisation of adaptive insulation systems for office buildings. Part 2: A parametric study for a temperate climate. Energy 2017, 127, 634-649. [CrossRef]

40. Carattin, E.; Franz, M.; Luciano, S. Materiali Isolanti. Nuove Tendenze in Architettura, IUAV di Venezia, Archivio Delle Tecniche e dei Materiali per L'architettura e il Disegno Industriale. Available online: http:/ / www.iuav.it/SISTEMA-DE/Archivio-d/approfondi/materiali-/SAIEnergia_definitivo.pdf (accessed on 18 August 2017).

41. Jelle, B.P. Traditional state-of-the-art and future thermal building insulation materials and solutions-Properties requirements and possibilities. Energy Build. 2011, 43, 2549-2563. [CrossRef]

42. Cucchiella, F.; D'Adamo, I. Estimation of the energetic and environmental impacts of a roofmounted building-integrated photovoltaic systems. Renew. Sustain. Energy Rev. 2012, 16, 5245-5259. [CrossRef]

(C) 2017 by the authors. Licensee MDPI, Basel, Switzerland. This article is an open access article distributed under the terms and conditions of the Creative Commons Attribution (CC BY) license (http://creativecommons.org/licenses/by/4.0/). 